\title{
The COVID-19 Pandemic: How Pastors Communicate Faith and Hope to Virtual Congregations
}

\author{
Naidoo GM \\ Department of Communication Science \\ University of Zululand, South Africa \\ kevinaidoo@yahoo.com \\ Connie Israel \\ Faculty of Accounting and Informatics \\ Durban University of Technology, South Africa \\ Magdalene Kevisha Naidoo \\ Empangeni Christian School, South Africa \\ Doi: https://doi.org/10.46222/pharosjot.102.210
}

\begin{abstract}
This paper examines how pastors engaged an online presence to preach the Word of God and address the needs of their congregations, during the crisis of the Covid-19 pandemic lockdown in South Africa. This is set against the Biblical instruction of Jesus Christ to Peter, to "feed my sheep" in John 21: 17, as it is the very same instruction that holds for pastors in churches today. However, the normal operations of the ministry have changed since the COVID-19 pandemic. The Christian church, a close-knit group of believers to whom social and physical distancing are foreign concepts, has had to adapt. Worship sites have been abandoned, and the absence of worshipers has become the norm. Pastoral ministries have been disrupted and call for pastors to embrace new technology to ensure that they have a digital presence with their congregation through social media. This paper argues that these circumstances give the church of God a unique opportunity to rethink how to continue ministry without physical contact. It adopted a mixed methods (qualitative and quantitative) approach, using an online questionnaire and telephonic surveys to engage pastors. The paper utilises the Two-way Communication Model (TCM) and the Uses and Gratification Theory (UGT). It concluded that pastoral care and spiritual counselling are essential in crises, that pastors have embraced social media in their mission, and that there is support for digital technology. The article recommendations that there should be a balanced communication strategy for Pastor's ministries, and that government partners with faith-based organisations in different ways in a joint effort to combat the virus, while encouraging and supporting congregants.
\end{abstract}

Keywords: COVID-19 Pandemic, Social Distancing, Digital Presence, New Technology, Gospel

\section{Introduction}

The COVID-19 pandemic has significantly disrupted the world order due to lockdowns that have brought the world to a pause. These lockdowns have also led to the enforcement of limited social interaction and the maintenance of physical distancing. This meant that the church could not assemble for worship, as required of every believer, under South Africa's Lockdown levels 4 and 5. Thus, in South Africa, church attendance ceased. Home visits and what are known as cell groups (small gatherings at members' homes) ceased. Yet the need for pastoral care and counselling increased, as church faced, globally, the devastating effects of wave after wave of 
the pandemic. In this context, this paper asks, how do pastors communicate faith and hope to virtual congregations?

Ministry has always been an essential component of a community of believers in the Christian church. Serving the community meant taking care of the sick, poor, broken-hearted; helping families that face bereavement and counselling those that experience loss, illness, substance abuse, physical and emotional abuse, and providing general spiritual counsel for the congregation. All these form part of practical ministry. The COVID-19 lockdown meant that traditional methods of ministry had to be revisited. This led ministers of the Gospel to venture into new ways of reaching their congregations with messages of faith and hope.

The COVID-19 pandemic has infected and affected many people from all walks of life, and noone is immune to this phenomenon. Swain and Badenhorst (2020) state that these are unprecedented times, and that there is no doubt that the pandemic has had a huge impact on South Africa's faith community. The government in March 2020 instituted the lockdown without considering the spiritual needs of people but has placed the church in isolation (Swain and Badenhorst, 2020). Kosmidis (2020) observes that globally, governments instituted lockdowns to limit the spread of the coronavirus and limited human social and religious activity. At a time when people needed hope and faith, they were made to feel disconnected and lonely, and in the process losing their loved ones, their jobs, and their confidence in the future. Pastors are usually the ones that people tend to turn to for help and consolation. However, pastoral consultations and home visits ceased due to the lockdown regulations. Did ministry cease? The answer is a resounding No, as technology then became the bridge between the clergy and the laity. The online communication of sermons, praise and worship, and broadcasting messages of encouragement of faith and hope have become a common practice among pastors, who took to using social media to connect with their congregations. This paper, therefore, looks at how pastors communicated faith and hope to their virtual congregations.

\section{The Aim of the Research}

The paper examines how pastors have communicated faith and hope to a virtual congregation during the COVID-19 lockdown.

\section{Objectives}

The following objectives were identified:

- To determine how pastors contacted their congregations during the COVID-19 pandemic lockdown.

- To determine if pastors established an online presence during this lockdown.

- To establish how pastors responded to members who lost their loved ones because of COVID-19 pandemic.

- To determine the challenges pastors experienced in their ministry during the lockdown.

- To establish the effectiveness of the new virtual systems.

\section{Literature Review}

Shutting down places of worship in a country where people are religious or practice their faith (Swain and Badenhorst, 2020), implies many things. According to Swain and Badenhorst (2020), with "the unique threat of the COVID-19 virus, governments across the world (with systems ranging from totalitarian to democratic) have instituted exceptional and extraordinary measures 
which have restricted fundamental human rights in a way that would have been unimaginable three months ago". Mathe (2020) indicates that communities globally were disrupted by the coronavirus in late 2019. The virus spread widened when people gathered, and the resultant infections affected businesses and placed pressure on health systems. The pandemic has inevitably affected the church, although in general, many ministries which could afford television and radio airtime, continued to share the Gospel of Jesus Christ. Since the lockdown, Mathe (2020) notes that to preach the gospel, churches had to come up with innovative ways of doing so.

\section{Communicating with the congregation during the lockdown}

Pastors know that traditionally, they are expected to rise to the clarion call of the Lord Jesus Christ of "feed my sheep" (see John 21:15-17). All of this changed once the lockdown was instituted by the South African government in March 2020. South African communities are diverse, multicultural, and made up of both rural and urban communities, with varying socioeconomic levels. Ministries are found in all these communities. Providing spiritual food in the form of preaching and teaching the word of God during the lockdown, required pastors to adopt innovative methods such as using social media platforms to reach their congregants. These include WhatsApp, Facebook, Instagram, and Telegram amongst others (see Craigo-Snell and Johnson, 2020). While this may be relatively workable in urban areas, the pastors who are in rural areas face challenges when it comes to using technology such as social media. Swain and Badenhorst (2020) concur that technology allows for potential communication through online applications which enable the ministry to continue. However, many rural areas lack online connectivity and both pastors and congregants cannot afford data and airtime which are very costly, especially when many of them are not at work due to the lockdown or are unemployed.

\section{Establishing an online presence for ministry during lockdown}

Human communication deals with interpersonal practices, and interaction that is person-toperson physically. Under the current circumstances, pastors have adapted and used technology to stay connected with their members. Law (2020) mentions that faith communities did not let the lockdown stop them but were able to expand their function by engaging their congregation and other members of the community, through online mediums. By digitally reaching their people, they have managed to stay connected.

Shoba (2020) states that the lockdown has forced worship sites to close their doors, and this included churches, mosques, and other places of worship. According to Smith (2020), "during this season of isolation, digital groups can provide a touchstone and connection to the world outside. Also, pastors can likewise meet with digital group leaders and be connected far beyond what they could in person". Faith plays an important part in the lives of many South Africans (Tayob, 2018) and having empty worship sites is unprecedented (see Kosmidis, 2020). The COVID-19 lockdown dimmed the sounds of corporate worship, which is what faith communities usually enjoyed while being at worship sites. Since congregational members could not physically meet with one another, they started to go online to find encouragement and hope during this time of social distancing and lockdown (Shoba, 2020). The crisis has brought about the opportunity for ministries to use social media as a virtual place of worship. The church is everywhere. Shoba (2020) indicates that such action meant providing congregations with spiritual motivation, through daily devotionals, prayers, and sermons.

According to the Lutheran World Federation (2020), many churches were connected online during COVID-19. The recording of worship services and preaching meant utilising mobile phones. The 
sharing of hope was a strategy that was adopted by the Lutheran communications team to ensure that the church was open and available to their congregation during the lockdown (Lutheran World Federation, 2020). Similar measures have been taken by most other Christian denominations (see Craigo-Snell and Johnson, 2020).

\section{The needs of the people during the COVID-19 lockdown}

The needs of the congregation for spiritual care and advice are ongoing, under normal circumstances. Under COVID-19 circumstances, these needs remain, but the lockdown makes it a challenge for pastors to attend to these needs. Many pastors are ministering to their congregation for the first time under such circumstances and find themselves on a learning curve. Funerals, especially in African cultures, usually take a week, to ensure that relatives are given adequate time to be prepared and present. The lockdown regulations for all gatherings are currently capped at 50 individuals per gathering. This rule applies to funeral services as well (see Mlambo, 2020). Families who lose their loved ones, expect the pastor to officiate the funeral service. In churches, the pastor is required to apply for a permit as an essential service to conduct this funeral and other ministry functions (Swain and Badenhorst, 2020). Usually, funerals draw large crowds and with the restrictions in place, many are not allowed to attend. With limited numbers permitted to attend a funeral service, member funeral undertakers are streaming the funeral service live. This allows people to connect online and join the funeral ceremony (Naik, 2020).

The COVID-19 lockdown restrictions focused on the physical health of the people; however, the South African government has not considered their spiritual and day-to-day needs (Swain and Badenhorst, 2020). In Australia, Hennessy (2020) states that the Prime Minister has declared churches to be workplaces. This meant that churches were permitted to live stream services and have employees and volunteers assist the pastor with the live streaming production. Those who fall into this category must observe physical distancing measures. Moreover, visitations by pastors are permitted only if considered essential for the congregation, on important pastoral care matters (Swain and Badenhorst, 2020). South Africa's population is made up of $80 \%$ Christians and other religious affiliation (GCIS, 2021 and Joubert and Grobler, 2013). There are various religious faith-based organisations, constituting a powerful network that the government perhaps overlooked when placing restrictions for lockdown. Magezi (2019) avers that the church participates in community development and thus it could effectively engage the community.

According to Swain and Badenhorst (2020), South African regulations allow pastors to operate only if they have received the necessary permits. With permits, pastors can visit and assist members with their needs, including providing groceries. However, there are other spiritual needs that people have, such as those who suffer from grief and mental/psychological pain (Swain and Badenhorst, 2020). Everly (2000) notes that in times of crisis and disaster, many individuals seek out religious leaders. Furthermore, the felt needs of people are far more, compared to the medical and financial impact, which has also intensified.

The South African government's capacity to provide solutions has been shown to be limited. Some initiatives that are already implemented, reveal gaps, and not all citizens are assisted; some are overlooked. Though well-intended, these initiatives are unable to cater for the close, personal, spiritual guidance and comfort people require. It is equally important to note that with the pandemic and lockdown regulations, many feel depressed and have other psychological problems; there is also a negative impact on domestic/relational issues, which eventually lead to domestic violence (Swain and Badenhorst, 2020). Under level 3 of the lockdown, not much has 
changed except that church services are allowed but with restrictions. For large congregations to assemble with a restriction of 50 persons attending, is unreasonable and impractical. Thus, while Pastors are now regarded as essential services, they still require permits to function. They are required to ensure that all protocols are observed according to the Government Gazette (Notice 609 of 2020), during church services (Law Africa, 2020). Like all folk going to the supermarket, they wear masks, and their hands are sanitized, but no temperature recording is done, and physical distancing is non-existent.

\section{Challenges that pastors experienced during the lockdown}

Churches vary in size as well as in demographics. Financially, not all churches have funds in reserve. Finances are generated by members in tithes and offerings, and this sum is often just enough to cover ministry expenses. Due to the lockdown, when church services ceased, so did the collection of offerings and tithes (Malachi 3:10). Many churches also have community outreach programmes and through these, many needy households have been provided with funds and food parcels. Some of these programmes have been put on hold due to the lack of income. Onyulo (2020) asserts that offerings and tithes will continue to be low each week and this will affect various outreach programmes of the church. He (2020) notes further a pastor's observation that income has dropped, and he had no guarantee he would receive a full salary.

The concern is that the longer the lockdown remains, the more the challenges will intensify and increase. Moreover, some pastors never received a salary (Mathe, 2020), aligned with the Biblical exhortation to give as one purpose in one's heart. This giving is done without reluctance or any compulsion, but cheerfully (2 Corinthians 9:7). Regardless, ministries have responsibilities, and they are liable to pay their monthly bills. Some of the members of the congregation have continued to give through an Electronic Funds Transfer (EFT) but ministries in the townships face technological challenges and not many use banking apps. Under the current circumstances, also, not many can physically go to the bank and deposit any monies into the church account (Mathe, 2020), even if this was their normal practice.

\section{Online activity in the post the COVID-19 lockdown restrictions to connect digitally with the faith community}

The church of Jesus Christ plays an important role during crises such as the COVID-19 pandemic, and it will continue to be relevant post the pandemic. According to Mathe (2020), the "megachurch" concept is going to decrease, and digital ministry will gain more traction and participation. Small groups and personalised ministries that have strong relationships with their members will continue to grow, which will translate into retention and participation of members. Churches postCOVID-19 must see this as an opportunity to revisit and relaunch their ministry programmes to reconnect with their communities.

Furthermore, success will depend on how ministries adapted during the lockdown (Mungroo, 2020). Online platforms adopted during the lockdown have helped to connect people, if not physically. Several ministries have taken advantage of this and shared ministerial content successfully. Going forward, pastors must not abandon the use of online platforms but should develop a balanced communication strategy for their ministries. Online technology plays an important role in sharing information and is more cost-effective than the use of traditional television and radio channels. 


\section{Conceptual Framework}

Adom et al. (2016:6) indicate that a theoretical and conceptual framework provides a road map for research and firmly grounds the research in theoretical constructs. The aim of using two frameworks is to make the findings in the research more meaningful and acceptable to the theoretical constructs, and to ensure generalisability. Conceptual frameworks enhance research and at the same time, extend knowledge by providing both a clear map which drives the research in acquiring salient information. They also enhance the experimentation and rigour of research (Adom et al., 2016). According to Imenda (2014), two theoretical and conceptual frameworks give research life. This paper is conceptualised using both the Two-way Communication Model and Uses and Gratification Theory.

\section{Two-way Communication Model (TCM)}

Communication is vital for the sharing of information, and this is no different during the lockdown. Effective communication requires a process that allows for the participation of a sender and a receiver, who switch their roles. Figure 1 provides the two-way communication model. During the lockdown, pastors engaged online channels such as WhatsApp, Facebook, and ZOOM, to connect with their congregation. Online channels also come with challenges, such as noise, that are illustrated in Figure 1. The noise in this context is what is referred to as poor connectivity, slow internet speed, poor usage skills and file size, which cause the communication to be interrupted. The preacher is the sender, and the receivers are the members of the virtual congregation. Roles are reversed when members of the congregation provide feedback. During the lockdown, online communication and interaction have brought about a measure of comfort to congregants. Sharing messages of hope and encouragement has helped to ease the fear and concerns of members of the congregation.

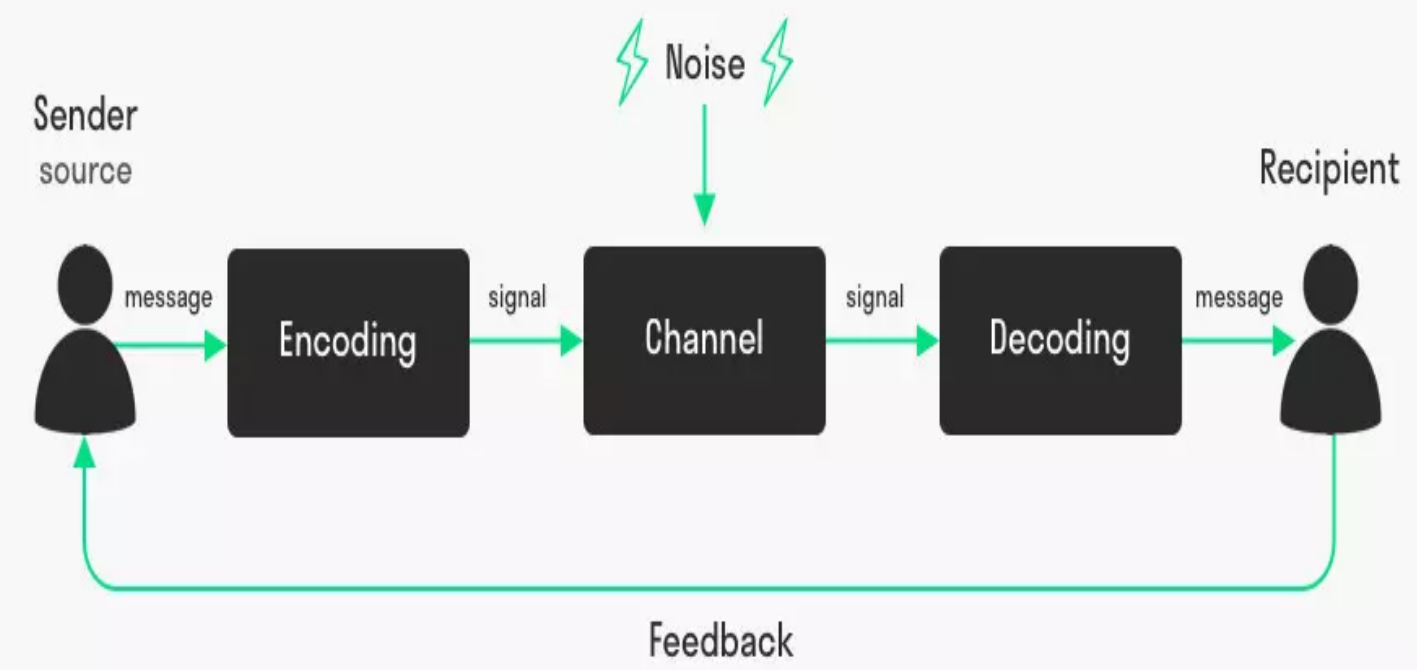

Figure 1: Communication Cycle model by Shannon and Weaver (1948)

Source: Adapted from Mulder (2016) 


\section{Uses and Gratification Theory (UGT)}

The lockdown has brought about a need for pastors to use technology to communicate with their congregation. Kats and Blumler's (1973), Uses and Gratification (UGT) Theory is used to show how people are generally affected by what is shared through online channels today. The use of online channels by pastors allows them to share their ministry content. These channels provide members of the congregation access to ministry content, now media content, by using their devices. Both the pastors and the members of the congregation, therefore, experience gratification. The pastor is gratified by connecting, as they are instructed to do Biblically (feeding the sheep), while the congregants are gratified that they can have their spiritual needs met.

The five concepts of UGT are Cognitive needs, Affective needs, Personal integrative needs, Social integrative needs, and Tension-release needs (see communicationtheory.org). These are outlined next in the context of the COVID-19 lockdown that is experienced by the Church:

- Cognitive needs - These focus on congregants connecting online to acquire information from the streaming of sermons and teachings. It brings them increased understanding and at the same time, pastors also meet their own cognitive needs, knowing that they are engaging their members and serving their purpose.

- Affective needs: The lockdown congregants are emotional, and their psychological needs are seen and heard, and often attributed to fear and anxiety. Information through media outlets concerning COVID-19 has brought mixed feelings and perplexity, since no one is immune to this virus. Pastors staying in contact with their congregations bring about a sense of comfort and reassurance through the sharing of God's Word.

- Personal integrative needs: Information is regarded as powerful, especially correct information. Congregants need confidence during the pandemic; they also seek status and conviction when they speak. Pastors must ensure that they speak with conviction, as this, in turn, helps congregants to hold onto their faith and hope.

- Social integrative needs: Both pastors and members of the congregation relate to others, such as family, friends, work colleagues and large social media communities. During this time of physical distancing and lockdown, the internet has become a lifeline that helps to address the social needs of both pastors and congregants.

- Tension-release needs: Many people during this time have engaged in other behaviours that divert and distract from the challenging situation the pandemic has brought to them. These e coping mechanisms. Some have turned to movies, binging on media services offered by Netflix, while others engage in gardening, baking, reading, and household maintenance. All of this assists them in some way to release their tension and feelings of fear.

Both TCM and UGT provide a possible framework that underpins this research. This is explained by the following diagram: 


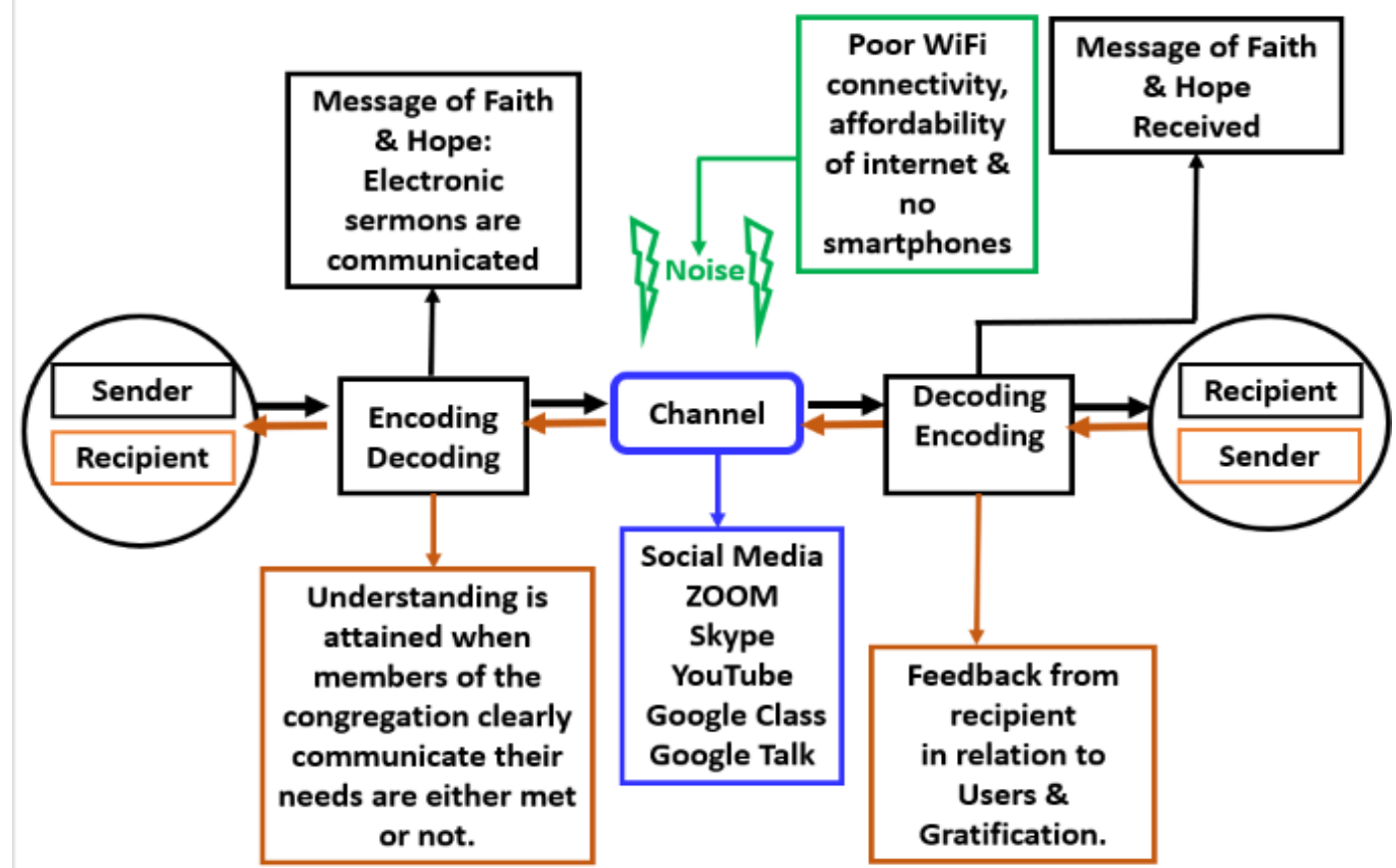

Figure 2: Online Communication flow during the COVID-19 Lockdown

During the pandemic, the Two-Way Communication Model (TCM) and Uses and Gratification Theory (UGT) could be used to reveal how pastors have continued ministry using technology during the COVID-19 lockdown. Figure 1 thus provides a framework for online communication using both TCM and UGT. This framework captures how pastors have shared and continue to share their messages using various online platforms. Those congregational members who are unable to connect are depicted under Noise in Figure 2 and must be reached using other methods such as voice call and SMS. Recipients (the congregation) receive the messages and provide feedback expressing some if not all the UGT concepts. This feedback is then received by the pastors who also are gratified with what UGT outlines and achieves.

\section{Research Methodology}

Both qualitative and quantitative methods were used for this research. According to Kelle (2006:309), quantitative and qualitative methods are different, yet they complement each other by fulfilling purposes within the research. Quantitative methods provide an overview of the field of the study. Qualitative methods allow the researcher to acquire local knowledge in the field of study. "This allows one to develop theoretical concepts and explanations that cover phenomena relevant to the research domain", as Kelle, (2006:309) asserts. Bengtsson (2016) states that qualitative research expands the understanding of diverse contexts of the human state. The qualitative component of this study was made up of content analysis, which comprised information from journal articles and websites that were relevant to the research. Moreover, open-ended questions were used in the online questionnaire.

The responses are summarised under themes that emerged from the various responses. The quantitative approach acquired data by developing an online questionnaire using Google Forms. The target audience for this research was made up of pastors from Durban and Empangeni, in KwaZulu-Natal and Benoni and Springs, in Gauteng. Respondents' participation was voluntary and anonymous. 
Due to the COVID-19 lockdown, a convenience sampling approach was adopted. Google Forms was used to develop the online questionnaire. The link was individually emailed and shared with respondents from different denominations; 74 pastors responded through the online survey and 6 pastors participated telephonically.

\section{Findings}

The findings are presented through several graphs providing insights into how Christian ministry was conducted during the COVID-19 lockdown. The data collection tools addressed the research objectives in terms of determining how pastors contacted their congregations during the COVID19 lockdown, if they established an online presence during this lockdown, how they pastors responded to members who lost their loved ones because of COVID-19, what challenges they experienced in their ministry during the lockdown, and how effective the new virtual systems were.

Quantitative data is provided first, on pastors' communication with their congregation, their use, and types of online platforms to conducting church services, and their frequency of communication. This is followed by qualitative data, focusing on two aspects, Pastors' responses to members who lost their loved ones because of COVID-19, and General comments on responses under lockdown provided by respondents.

\section{Quantitative data}

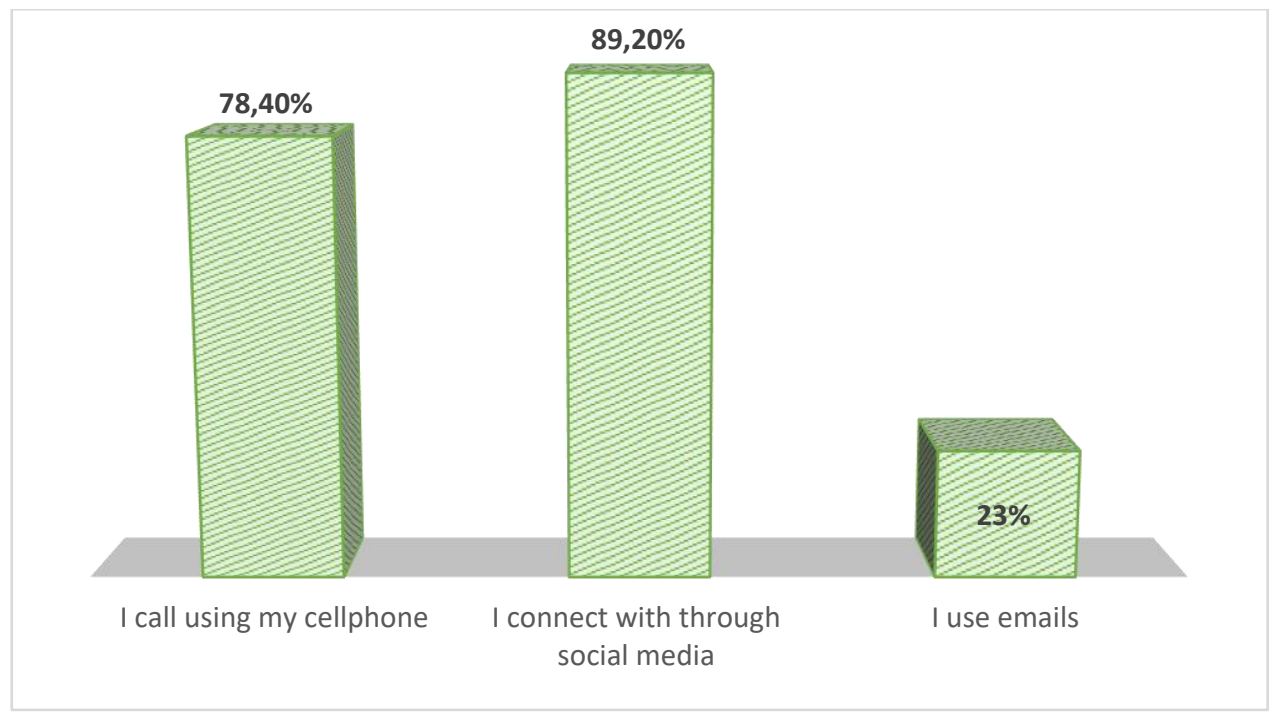

Figure 3: Communication with members of the congregation

Figure 3 depicts how pastors communicated with their congregational members using cellphones, social media, and emails during the COVID-19 lockdown. A combination of methods was possible. Pastors selected social media as the most popular at $89.2 \%$. Cellphone calls followed at $78.4 \%$ and this comprised calls and text messages sent to their church members. Emails were the least popular at $23 \%$. It would be interesting to see if the variables remain constant or the use of social media will increase post-COVID-19. 


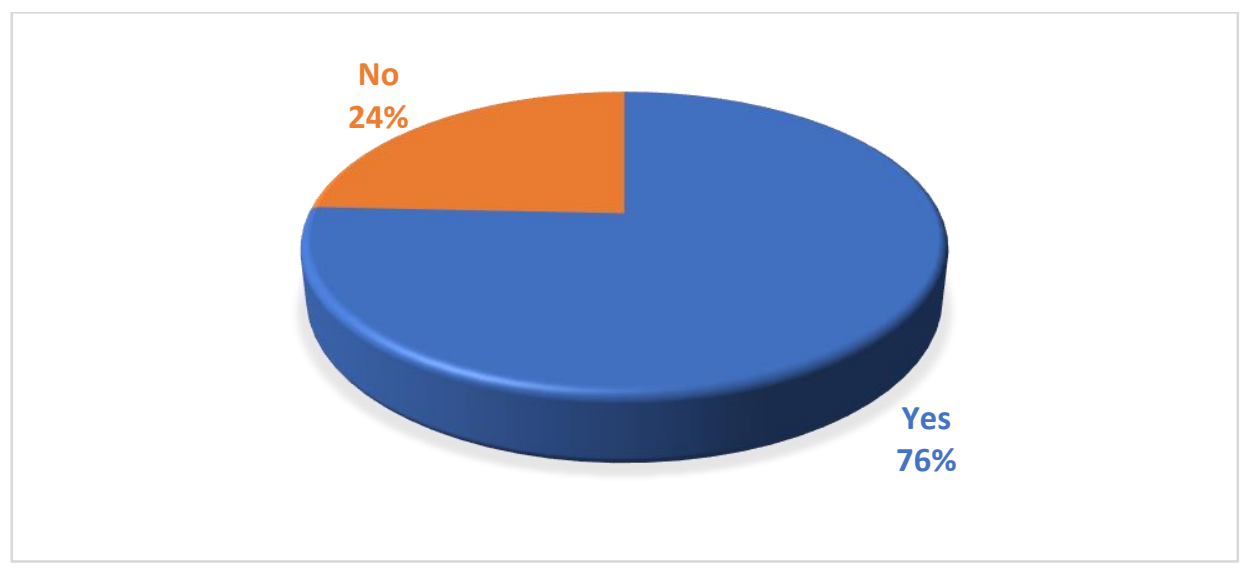

Figure 4: The use of online platforms to conducting church services

Pastors switched to online platforms since the government had closed worship sites under the regulations that were passed and published in the South African Gazette Notice 609 of 2020. Figure 4 shows that $76 \%$ of pastors were using online platforms to conduct services, with $24 \%$ not using online platforms for conducting services. This is concerning and may be attributed to many factors: especially during the lockdown, pastors may be based in rural communities, without the infrastructure of their urban counterparts, or unable to meet the costs of regular data and WiFi access.

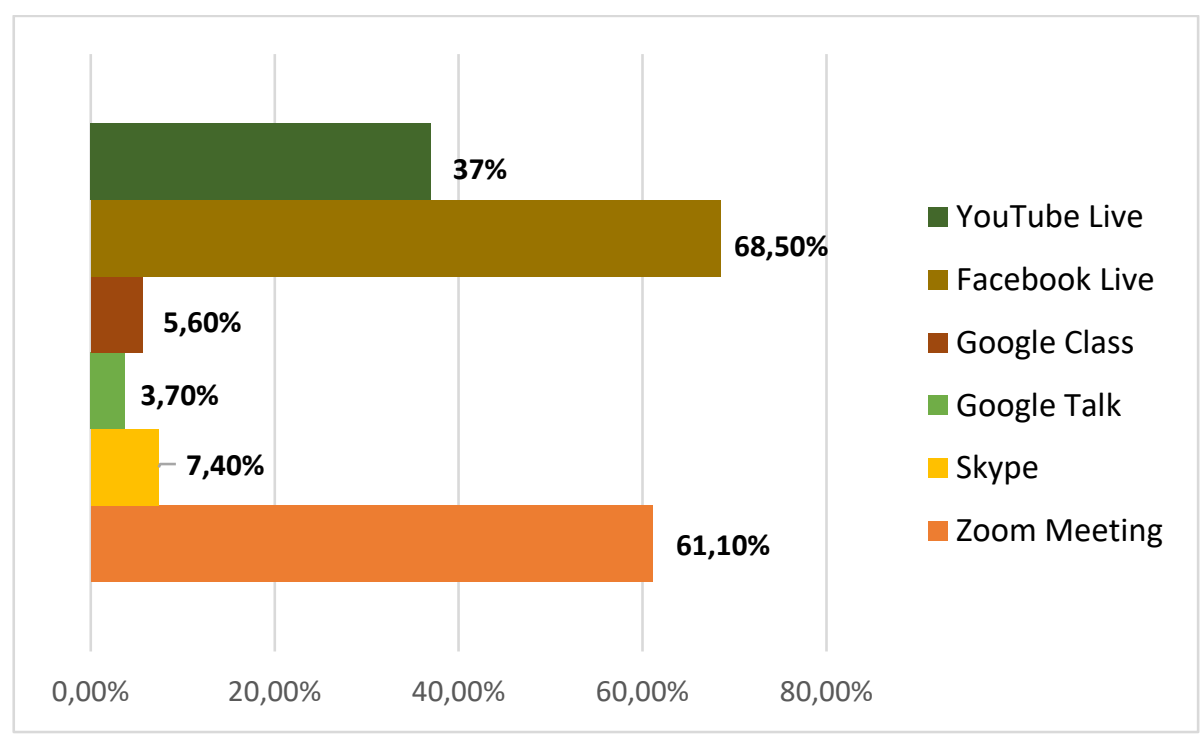

Figure 5: Types of online platforms used for church services

Figure 5 provides the various types of online platforms that pastors used for conducting services. Facebook live was selected by $68.5 \%$, a little over Zoom meetings at $61.1 \%$. YouTube live usage was $37 \%$ and other online platforms selected by respondents were under $10 \%$. According to 
Figure 5, both Facebook and Zoom were leading as the most popular online platforms during this lockdown.

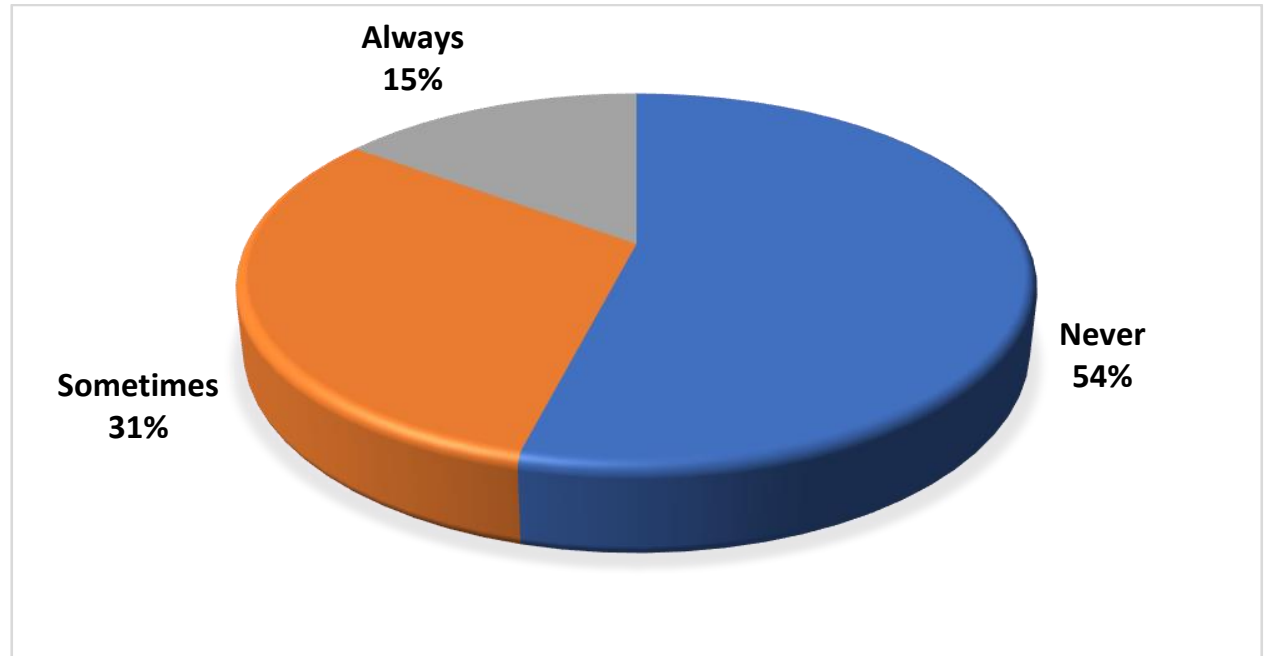

Figure 6: Stream Sermons through online Platforms before the Lockdown

Figure 6 illustrates the streaming of sermons by pastors before the lockdown. It is interesting to note that $54 \%$ of pastors started streaming their services for the first time. Those who streamed before the lockdown amounted to $15 \%$, and $31 \%$ indicated that they did so sometimes. Between the variable 'always' and 'never', approximately $69 \%$ of pastors were streaming their sermons online during lockdown.

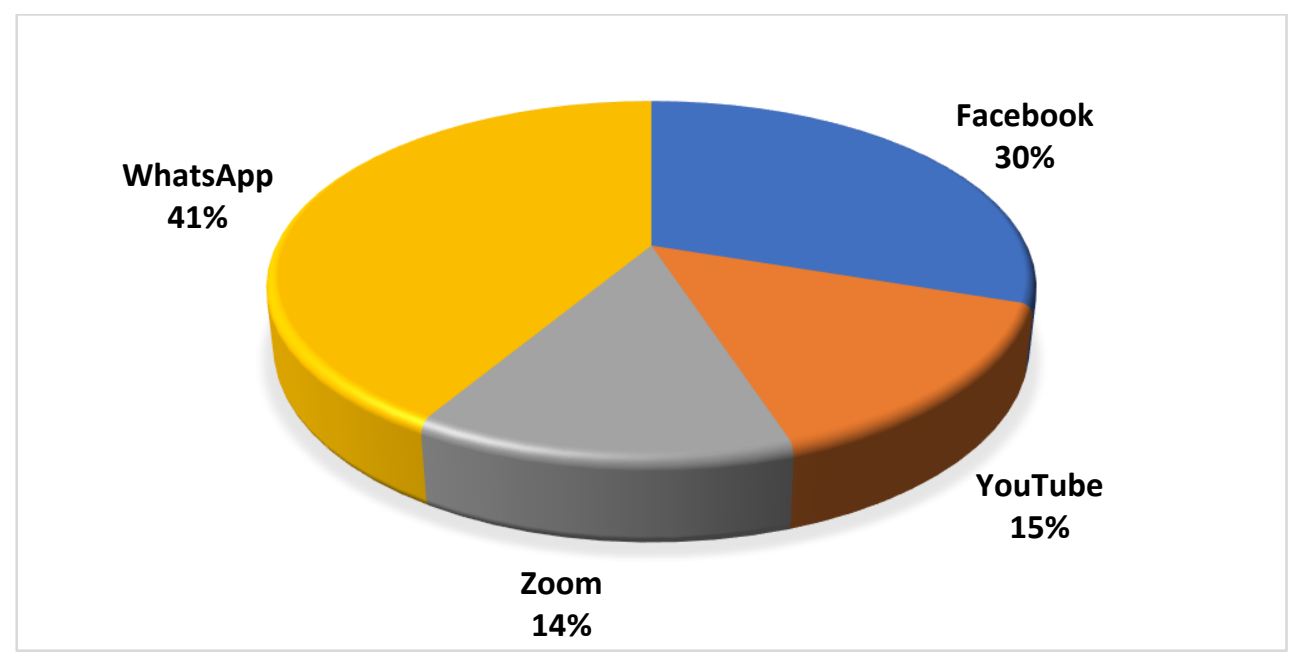

Figure 7: Social media platforms used during the lockdown to share sermons

Figure 7 depicts the various social media platforms used by pastors during the lockdown. The most popular choice of social media platform used by pastors was WhatsApp (41\%). Facebook $(30 \%)$ was the second choice of medium used. The remaining variables, YouTube (15\%) and Zoom (14\%), are still significant platforms for connecting with congregational members. 


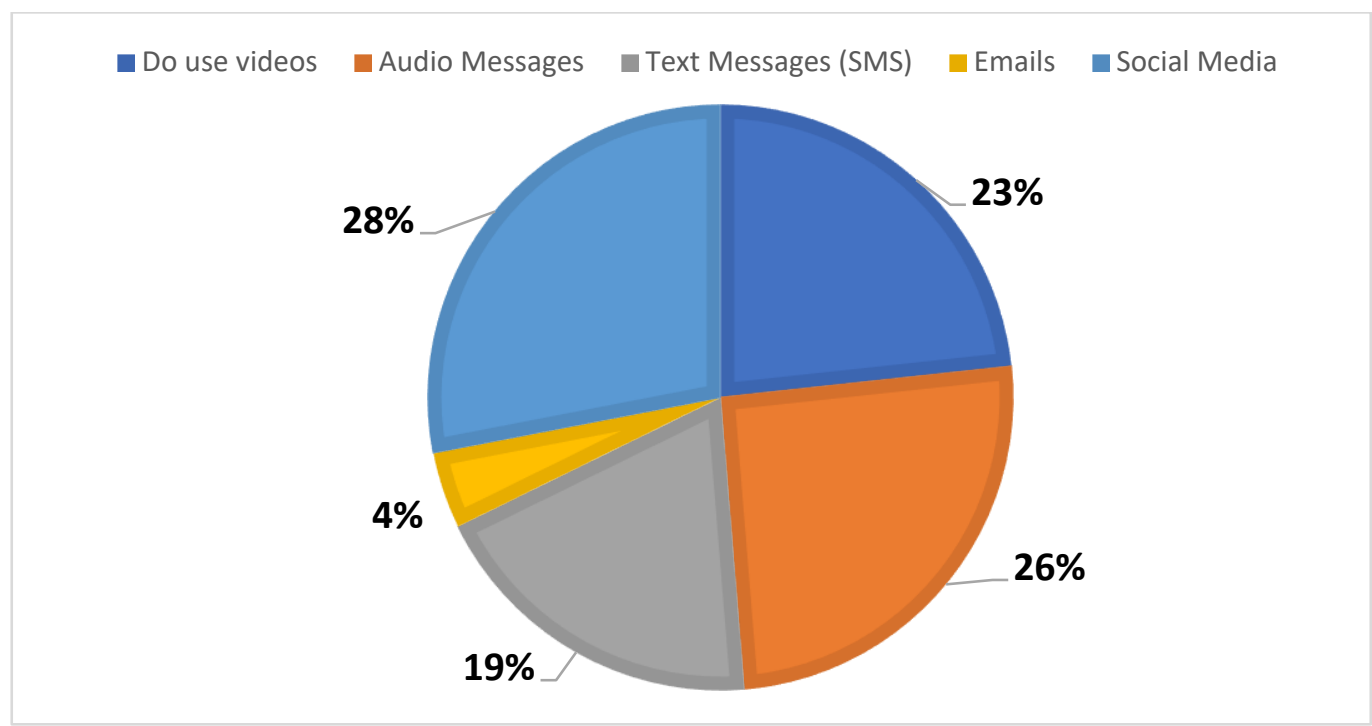

Figure 8: Forms of communication used during the lockdown

Figure 8 provides the different forms of communication that pastors used during the lockdown. Social media at $28 \%$ is the highest, with audio messages at $26 \%$ and videos at $23 \%$, as methods that can also be shared through social media. Pastors indicated that they used Text Messaging at $19 \%$. Finally, $4 \%$ indicated that they used Emails. It seems clear that pastors have embraced social media.

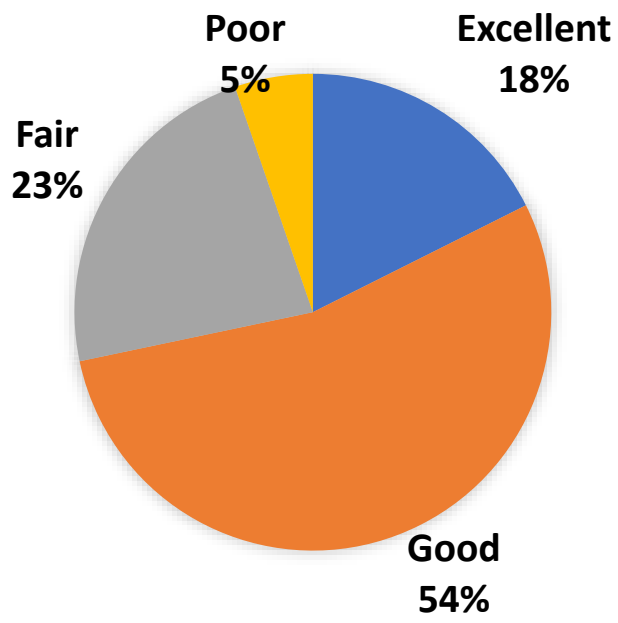

Figure 9: Online viewing of posts by members of the congregation

In Figure 9, pastors commented on their congregational members' online activity. The category Excellent constituted $18 \% .54 \%$ selected Good, and a further $23 \%$ of pastors indicated that members' participation was Fair. Interestingly, $5 \%$ of pastors rated members' participation was Poor. Given the variables during lockdown, the uptake of online participation has been largely 
successful.

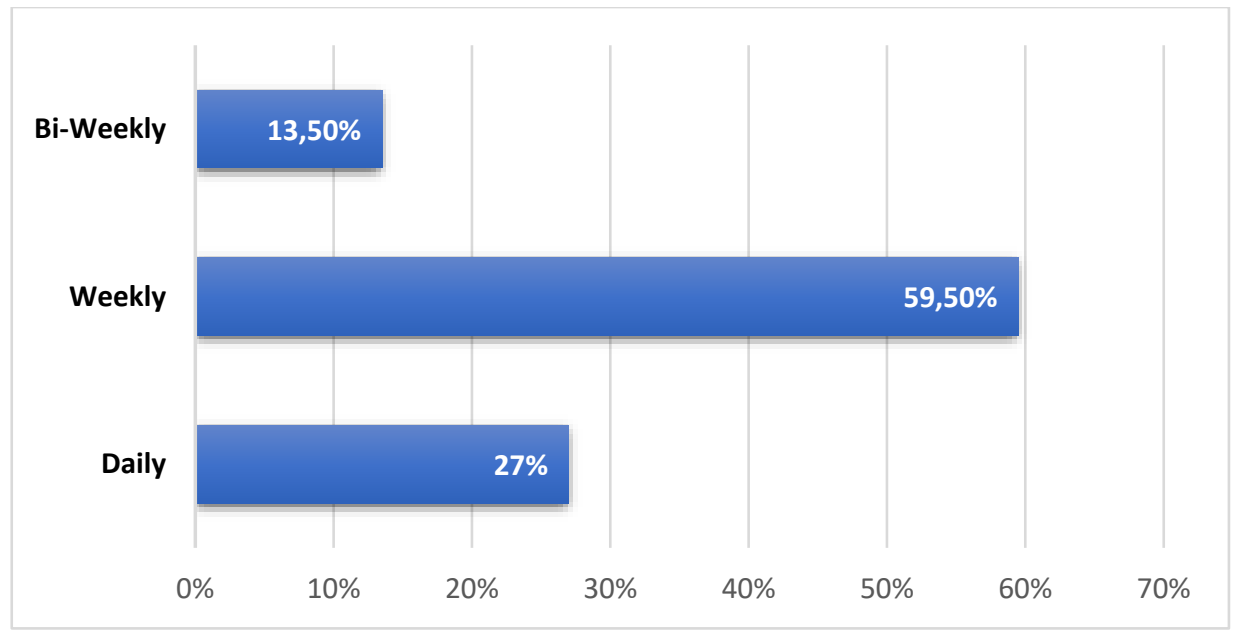

Figure 10: The communication frequency with individual members

Staying in touch with members of one's congregation during the lockdown was considered essential, and Figure 10 provides 4 variables of contact. Daily contact of members by pastors rated 27\%; $59.5 \%$ of pastors contact their members weekly. Pastors who contacted their members bi-weekly constituted $13.5 \%$. For the variable Month, there were no responses: no pastor communicated monthly. This reveals that pastors communicated frequently with their members, which must account for a degree of gratification for both.

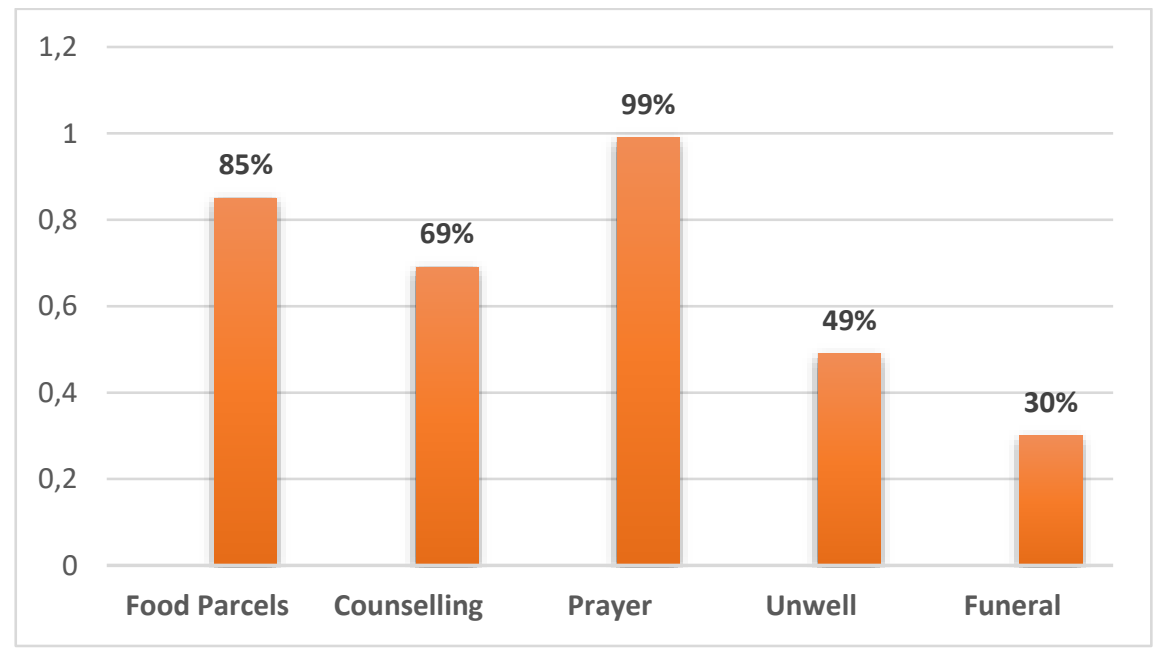

Figure 11: Have you received any requests from your congregation?

Lockdown and physical distancing brought about many challenges. Figure 11 focuses on pastors receiving requests from their congregations. The requests for prayer at $99 \%$ constituted the greatest need that pastors were called upon to manage. They indicated that food parcels at $85 \%$ rated as the second-largest need. Counselling at $69 \%$ was also revealed as a need. A total of $49 \%$ of pastors indicated that they received a request for support from congregational members who were feeling unwell. Pastors $(30 \%)$ also mentioned that they attended to funeral requests from members. 
The quantitative data thus revealed that pastors did contact their congregations and established an online presence during the lockdown, despite several challenges.

\section{Qualitative data}

The qualitative data gathered through the online questionnaires elicited deeper responses, indicating that pastors did respond to members who lost their loved ones because of COVID-19, again despite challenges, and that they regarded virtual systems to be not only necessary, but also useful in their ministry. Pastors' responses to members who lost their loved ones because of COVID-19 revealed some difficulty, as they acknowledged that this was an exceedingly difficult question: COVID-19 placed many uncertainties on everyone and everything. Any loss is difficult and with the pandemic, restrictions have exacerbated the loss and grief experienced. It was a new experience and there was, therefore, no clear mode of response except to continue by encouraging and sharing the hope that Christ has given us. Participants' responses were categorised under the following general themes:

Comfort and Care: During the long lockdown, church members have been frightened and needed spiritual comfort and care. Regular communication with their pastors through social media helped them to stay calm and brought some comfort. A special visit could be made especially if a loved one passed away. However, it was imperative that physical distancing rules and COVID-19 safety protocols were to be in place and adhered to always. This helped families with plans for the funeral. Also, financial assistance was offered, depending on the family's needs. In this time of loss, a message of hope, love, and faith was shared with the family members. In conducting funerals, all precautionary measures were to be observed, and pastors indicated that they worked

closely with the funeral undertakers. Furthermore, mourners who came to view the corpse were allowed in only if they were wearing masks and their hands were sanitized. Since only 50 people could attend a funeral, a virtual funeral was arranged for the extended family and mourners. After the funeral, during the period of bereavement, pastors indicated that they continued to pray online for the family and called members individually from time to time.

Spiritual Counselling: To counsel, pray and encourage with Biblical scripture, is the job of a pastor. His/her mission is to try to support family and individual members as much as possible, and in a practical as well as spiritual way. Counselling was thus done before and after the funeral, this time via online communication. Prayer was offered for families online and counselling continued if members of the family had difficulty coping and showed signs of emotional instability.

Prayerful Support: Due to COVID-19, offering prayer and support was given through online platforms such as Zoom, WhatsApp and telephone calls. The goal was to encourage congregants with a message of faith and hope from the Word of God.

\section{General comments on Responses under lockdown provided by respondents}

General comments were also provided by pastors concerning ministry and the lockdown and are summarised as follows:

Use of online technology: Pastors indicated the use of online technology was not without challenges since not all members of their congregations had data to access online material. Data is expensive, and with the lockdown, some had lost income. Online access was thus a luxury. Ministering to communities especially in township informal settlements, through social media, is not so easily done, given poor internet connectivity and affordability. Despite the challenges posed 
using social media from time to time, pastors indicated that technology had become an additional tool to spread the Gospel and to expand the Kingdom of God. During this time, technology helped to view many local and international ministries, which has been a wonderful blessing and encouragement. Technology was considered necessary to communicate the Gospel and to keep in touch with the people, although it can never replace personal contact. Pastors indicated that the church at large must maintain both an online and offline presence when sharing the Gospel of Jesus Christ. Pastors mentioned during this time, the call to persevere in all circumstances and carry the Gospel message faithfully in season and out of season: this must remain the focus. Technology was both good and bad; therefore, when using it for the ministry, it must be done responsibly.

The Church is Essential: It rather sad and disappointing that the Church was not regarded as an essential service in South Africa at the time of lockdown. The Church of God is positioned to assist the government during such times as these and to help encourage communities. This pandemic has helped the church to reflect on what its ministry engagements are, and thereby, to readjust its missional purposes. Many people are currently desperately in need of God and are hurting and uncertain about their future. Due to the restrictions, reaching out to informal settlements and rural areas especially has proved to be a great challenge, as many have no phones. Due to the low or no income in churches, not much could be done to redress this challenge, not was much done by government. Trying to preach to the hungry is not easy.

Ministry needs: Tithes and offering have been reduced. The financial structure of the church and maintenance of the church remains a huge challenge, as everything depends on having finances. With low-to-no income, ministries cannot meet their budgets, rental and other ministry needs, some of which have become non-existent. Salaries for church workers and pastors have been halved, and some have not been paid at all. Community projects that rely on churches for funding have also suffered, with some closing down.

\section{Conclusions and Recommendations}

The world is going through an unprecedented time of crisis and uncertainty, given the COVID-19 pandemic and other global tragedies, like terrorism, corruption, climate change and poverty. Regarding the pandemic, infection rates are on the increase and media outlets continue to report a bleak outcome. The pandemic has shrunk global economies which has had a knock-on effect on business and employment. Many families are facing great challenges, and many are affected by their loved ones who are infected with the COVID-19 virus.

The South African government asserts it is doing its best, and is currently overwhelmed, given the great needs that have arisen due to the pandemic. People under these extreme conditions need to be encouraged with hope and faith. Many people during this time are lonely, experiencing the loss of loved ones, losing their jobs, and facing great fear as to what their future will be. These are just some of the realities occurring in the communities of our country. As a key member of the community and the Church, a pastor's greatest responsibility is to be always feeding the sheep, following the teaching and preaching of the Word of God.

This study has shown that pastors not only contacted their congregations but established an online presence during the lockdown in South Africa; moreover, they found ways to respond to the calls for comfort during bereavement caused by the COVID-19 virus. The challenges they have faced during lockdown thus far are varied but did not deter them from their mission. Pastors have a significant role to play as bearers of faith and hope, and that pastoral care and spiritual counselling are essential in crises. Pastors have embraced social media in their mission and show 
significant support for digital technology. The findings of the research correlate with the literature review and support the effectiveness of the new systems of digital technology adopted by pastors to connect with their congregation. The increased streaming of services with over half the respondents who never did so before, is significant, with online services becoming the new normal. Members' participation in online services has also increased. Pastors have established good communication with members regularly and this is besides accessing online services.

The Church of God is an established and essential conduit that government must recognise, as well as the many other faith-based organisations that are within the various communities of South Africa. To assist in combating the virus, it is recommended that the government partners with faith-based organisations in various ways: the distribution of food parcels, the screening of community members for the coronavirus, the conversion of worship sites to accommodate the influx of infected persons needing care and could also be used as vaccination centres if the need arises.

It is vital for pastors to continue with their ministry, for themselves, the congregants and the community at large. To this end, pastors should continue to use online communication such as social media to reach their congregations. Using this method, they can connect digitally to each group and perhaps cast a wider net, as using technology provides the opportunity to connect with far more people than one would in person (see Smith, 2020). Finally, it would be interesting as a future study to ascertain how the ministry will function post-COVID-19, and specifically whether pastors will continue to maintain a digital presence or revert to traditional, face-to-face ways of sharing the Gospel. The level of gratification experienced is also an area for further exploration.

\section{References}

Adom, D., Adu-Gyamfi, S., Agyekum, K., Ayarkwa, J., Dwumah, P., Abass, K., Kissi, E., OseiPoku, P. \& Obeng-Denteh, W. (2016). Theoretical and conceptual framework: Mandatory ingredients of a quality research, Journal of Education and Human Development, 5(3), pp.158172.

Bengtsson, M. (2016). How to plan and perform a qualitative study using content analysis, Nursing Plus Open, 2, 8-14.

Communicationtheory.org. (2020). Communication Theory. Available at https://www.communicationtheory.org/uses-and-gratification-theory/ Accessed 15 June 2020.

Craigo-Snell, S. \& Johnson, T.E. (2020). Pandemics, Protests, and Performances: Embodying Our Faith in an Unexpected Season: Introduction, Liturgy, 35(4), 1-7.

Everly, G.S. (2000). The role of pastoral crisis intervention in disasters, terrorism, violence, and other community crises. International journal of emergency mental health, 2(3), 139-142.

GCIS. (2021). Pocket Guide to South Africa 2011/2012. Available online at https://www.gcis.gov.za/content/resourcecentre/sa-info/pocket-guide-south-africa-20112012 Accessed 19 May 2021.

Hennessy, A. (2020). Coronavirus crisis: Prime Minister Scott Morrison says churches to be considered 'workplaces' for Easter. Available online at https://www.perthnow.com.au/news/coronavirus/coronavirus-crisis-prime-minister-scott- 
morrison-says-churches-to-be-considered-workplaces-for-easter-ng-b881509039z Accessed 19 May 2021.

Imenda, S. (2014). Is There a Conceptual Difference Between Conceptual and Theoretical Frameworks? Journal of Social Science, 38(2), 185-195.

Joubert, Y. \& Grobler, A. (2013). The value and extent of religious participation of members of the South African Police Service (SAPS), HTS Theological Studies, 69(1), 1-10. Available at http://www.scielo.org.za/scielo.php?script=sci_arttext\&pid=S0259-

$94222013000100001 \&$ Ing=en\&tlng=en. Accessed 19 May 2021.

Katz, E., Blumler, J. G. \& Gurevitch, M., (1973). Uses and Gratifications Research. The Public Opinion Quarterly, 37(4), 509-523. Available at http://www.jstor.org/stable/2747854 Accessed 19 May 2021.

Kelle, U. (2006). Combining qualitative and quantitative methods in research practice: Purposes and advantages. Qualitative Research in Psychology, 3(4), 293-311.

Kosmidis, N. (2020). A Search for a Theology of Life: The Challenge of COVID-19 for Orthodox Ecclesiology and Religious Practices. The Ecumenical Review, 72(4), 624-635.

Law. T. (2020). 'It's Like a Lifeline.' How Religious Leaders Are Helping People Stay Connected in a Time of Isolation. Available at https://time.com/5813521/religion-coronavirus/Accessed 18 May 2020.

Law.Africa (2020). Directions Relating to Norms and Standards for Religious Gatherings repealed. Available online at https://openbylaws.org.za/za/act/gn/2020/609/eng/ Accessed 18 May 2021.

Lutheran World Federation. (2020). COVID-19: Isolated physically, engaged digitally. Available at https://www.lutheranworld.org/news/covid-19-isolated-physically-engaged-digitally Accessed 20 May 2020.

Magezi, V. (2019). Doing public pastoral care through church-driven development in Africa: Reflection on church and community mobilisation process approach in Lesotho. HTS Theological Studies, 75(4), 1-11.

Mathe, T. (2020). Churches are struggling in lockdown. Available at https://mg.co.za/business/2020-05-07-churches-are-struggling-in-lockdown/ Accessed 18 May 2020.

Mlambo, S. (2020). Funerals will be allowed during lockdown, but capped at 50 mourners Bheki Cele. Available online at https://www.iol.co.za/news/south-africa/funerals-will-be-allowedduring-lockdown-but-capped-at-50-mourners-bheki-cele-45550569 Accessed 19 May 2021.

Morgan, T. (2020). 7 Shifts Churches need to make because of the Coronavirus. Available online at https://tonymorganlive.com/2020/04/15/7-church-shifts-coronavirus/ Accessed 10 June 2020. 
Mulder, P. (2016). Communication Cycle model by Shannon and Weaver. Available online at https://www.toolshero.com/communication-skills/communication-cycle-shannon-weaver/ Accessed 5 May 2020.

Mungroo, P. (2020). Closed but connected: How church communities are coping with Covid-19. Available online at https://socialinnovation.blog.jbs.cam.ac.uk/2020/04/22/closed-but-connectedhow-church-communities-are-coping-with-covid-19/ Accessed 5 May 2020.

Naik, S. (2020). How SA funeral homes are embracing technology during the Covid 19 pandemic. Available online at https://www.iol.co.za/saturday-star/news/how-sa-funeral-homesare-embracing-technology-during-the-covid-19-pandemic-49309770 Accessed 18 May 2021.

Onyulo, T. (2020). Christians Debate Paying Tithes to African Churches Closed by Coronavirus. Available online at https://www.christianitytoday.com/news/2020/april/kenya-rwanda-churchestithes-coronavirus-covid-19-offerings.htmlAccessed 10 June 2020.

Shoba, S. (2020). Worshippers gather online for prayer and fellowship. Available online at https://www.dailymaverick.co.za/article/2020-04-09-worshippers-gather-online-for-prayer-andfellowship/\#gsc.tab=0 Accessed 15 May 2020.

Swain, M. \& Badenhorst, N. (2020). COVID-19 Lockdown: A Case for Limited Exemption for Religious Organisations. Available online at https://forsa.org.za/covid-19-lockdown-a-case-forlimited-exemption-for-religious-organisations/ Accessed 18 May 2020.

Smith, J. (2020). COVID-19 Lockdown: Keeping Churches Connected while Sheltering in Place. Available online at https://um-insight.net/in-the-church/local-church/covid-19-lockdown-keepingchurches-connected-while-shelterin/Accessed 20 May 2020.

Tayob, A. (2018). The representation of religion in religion education: Notes from the South African Periphery. Education Sciences, 8(3), 146. 